\title{
The Nutritive Value of the Meat Quality of Locally Breed Chicken, Exotic Chicken and Turkey
}

\author{
Ogunmola, O. O., Taiwo, O .F. and Ayankoso, A. S. \\ Department of Chemistry Emmanuel Alayande College of Education P.M.B 1010, Oyo
}

\begin{abstract}
Locally breed Chicken, exotic Chicken and Turkey were obtained from Ajegunle market in Oyo town and processed for their proximate composition and dietary minerals. The proximate composition reveals that the moisture content in percentage ranged from $5.00 \%$ in Turkey to $0.50 \%$ in exotic Chicken, the ash content ranges from $6.50 \%$ in Turkey to $2.00 \%$ in locally breed chicken. The fat content ranges from $18.0 \%$ in Turkey to $3.70 \%$ in locally breed Chicken; the protein content ranges from $68.97 \%$ in exotic Chicken to $50.95 \%$ in locally breed Chicken. Carbohydrate content ranges from $25.83 \%$ in locally breed chicken to $0.63 \%$ in Turkey. The fibre content of Turkey was $2.22 \%$ and $1.96 \%$ in local Chicken while fibre content was not detectable in exotic Chicken. The dietary minerals that were in abundance in the meat samples are Potassium whose concentration ranged from $603 \mathrm{mg} / 100 \mathrm{~g}$ in Turkey to $527 \mathrm{mg} / 100 \mathrm{~g}$ in exotic chicken. Sodium ranged from $370 \mathrm{mg} / 100 \mathrm{~g}$ in Turkey to $345 \mathrm{mg} / 100 \mathrm{~g}$ in exotic chicken. Calcium ranged from $575 \mathrm{mg} / 100 \mathrm{~g}$ in Turkey to $375 \mathrm{mg} / 100 \mathrm{~g}$ in exotic chicken while Magnesium ranged from $377 \mathrm{mg} / 100 \mathrm{~g}$ in local chicken to $256 \mathrm{mg} / 100 \mathrm{~g}$ in exotic chicken, Iron ranged from $465 \mathrm{mg} / 100 \mathrm{~g}$ in local chicken to $233 \mathrm{mg} / 100 \mathrm{~g}$ in Turkey. Zinc ranged from $622 \mathrm{mg} / 100 \mathrm{~g}$ in exotic chicken to $475 \mathrm{mg} / 100 \mathrm{~g}$ in Turkey.

Keywords: Proximate Analysis, Dietary Mineral, Chicken Meat, Meat Quality
\end{abstract}

\section{Introduction}

Poultry are farmed in great numbers, chicken being the most numerous. Poultry farming involves domesticating birds such as Chickens, Turkeys, Ducks and Geese. They are raised purposely for their meat and eggs. Chickens raised for eggs are usually called laying hens while chickens raised for meat are often called broilers. Poultry farming in the past used to entail throwing corn out to wandering chickens to pick up, and these chickens lay their eggs where they so wish. Egg production under this conventional system of rearing in the villages is very low. This is generally due to the insufficient feed supply and problem of diseases and social behavior (Ibe 1998). Egg production when raised extensively is about 40 eggs per year (Ikeobi et al., 1996) whereas under improved conditions, egg yields of local birds may be doubled (Nwosu 1979)

Exotic chickens are raised in specialized caging system, they are fed with specially formulated feeds which are rich in essential minerals, their growth are controlled and the egg production are monitored and controllable using feed formulation and vaccines. These exotic breeds are never allowed to range freely or scavenge for food. Turkey on the other hand is a large poultry bird that originated from the temperate parts of the world which is now a popular form of poultry in other parts of the world. Ancient Mesoamericans domesticated this subspecies, using its meat and eggs as major sources of protein and employing its feathers extensively for decorative purposes (UF Researchers 2012). Unlike chicken, duck, and quail eggs, turkey eggs are not commonly sold as food due to the high demand for whole turkeys and lower output of eggs as compared with other fowl. The value of a single turkey egg is estimated to be about US $\$ 3.50$ on the open market, substantially more than a carton of one dozen chicken eggs (Cecil 2012)

A lot of information abounds in literature on meat quality, nutrient status and nutritional composition of some animal meat. According to morphological perspective, it has been established that differences exist between pure indigenous, exotic and the crossbred chickens. It was reported that poultry breeding in Nigeria started in 1985 at the National Animal Production Research Institute, Zaria (Adebambo 1992). It has been reported that crossbreeding indigenous chicken with exotic improves the body weight greatly at 12 weeks (Nwosu 1979) and (Adeniyi et al., 2011). And that crossbreeding indigenous chicken with exotic breed will go a long way to enhance better productivity of these indigenous stocks and also help in planning sustainable breeding programme for future.A report of the proximate composition of beef, broiler meat, African catfish and tilapia reveal that all the meat types analyzed had no crude fibre and that beef had the highest lipid content of 4.59\% followed by broiler meat $4.34 \%$, tilapia $3.35 \%$ while the least value came from African catfish $3.18 \%$. It was also reported that beef is relatively superior to other meat types in terms of protein and fat content while tilapia was the cheapest source of animal protein in the study (Nwosu et al.,1980) in a similar report that compared the proximate composition and fatty acid profile of Anurans meat with Chicken meat (Nielson et al (1988), the moisture content of chicken meat $(76.03 \pm 0.15 \%)$ was significantly lower than both the anurans meat 
(77.73\% and $82.87 \%)$. Fat and ash content when compared to the edible portion of anuran, chicken meat had $14.48 \pm 0.18 \%$ of protein which was lower compared to anurans.

\section{Materials And Methods}

Turkey, exotic Chicken and local Chicken used for this study were obtained from Ajegunle market in Oyo, Atiba Local Government in Oyo State. Sample pre-treatment include the mercy killing of the three bird samples. The feathers were plucked using boiled water, each samples were then cut into smaller pieces and later parboiled in hot water. The parboiled meat was then smoked and sun dried (oven was not used so that the volatile minerals will not escape).The dried samples were then milled into powder using Kenwood blender. The samples were stored in polyethylene containers for further analysis. All the chemicals used for the experiment are analar grade. Proximate analysis including the moisture the ash, crude fibre, and crude carbohydrate were determined by the method described by (AOAC 1990). The ten dietary minerals analyzed: K, Na, Ca, Mg, P, Fe, $\mathrm{Mn}, \mathrm{Cu}, \mathrm{Pb}$ and $\mathrm{Zn}$ were determined by AAS.

III. Results And Discussion

Table 1: Proximate composition of the meats in percentage (\%)

\begin{tabular}{|l|l|l|l|l|l|l|}
\hline Sample & $\begin{array}{l}\text { Moisture } \\
\text { content }\end{array}$ & $\begin{array}{l}\text { Ash } \\
\text { content }\end{array}$ & $\begin{array}{l}\text { Fat } \\
\text { content }\end{array}$ & $\begin{array}{l}\text { Fibre } \\
\text { content }\end{array}$ & $\begin{array}{l}\text { Protein } \\
\text { content }\end{array}$ & $\begin{array}{l}\text { Carbohydrate } \\
\text { content }\end{array}$ \\
\hline $\begin{array}{l}\text { G.gallusdomesticus } \\
\text { (Local chicken) }\end{array}$ & 7.50 & 2.00 & 11.76 & 1.96 & 50.95 & 25.83 \\
\hline $\begin{array}{l}\text { M. } \\
\text { Gallopavo(Turkey) }\end{array}$ & 5.00 & 6.50 & 18.06 & 2.22 & 67.59 & 0.63 \\
\hline $\begin{array}{l}\text { Gallus domesticus } \\
\text { (Exotic Chicken) }\end{array}$ & 0.50 & 4.00 & 3.70 & ND & 68.97 & 22.83 \\
\hline
\end{tabular}

$\mathrm{ND}=$ not detectable at that limit.

The result of the proximate composition of Turkey, exotic Chicken and local Chicken Meats were presented in Table 1. Out of the three meat samples examined, the ash content of locally bred chicken is the lowest compared to the other two meat samples. The ash content is $6.50 \%$ in Turkey, $4.0 \%$ in exotic Chicken and $2.00 \%$ in local chicken. The values recorded for the three samples are however higher than those reported as the common range of ash present in poultry meat (0.7-1.3\%).Nielson (1988). Ash in food determines largely the extent to which the dietary minerals would be available in a particular food sample. It also determines the rate at which food substances would make available the amount of energy locked in it. This implies that Turkey could furnish man with more energy and some viable minerals than the remaining meat sources.

Out of the three samples examined, moisture content is $5.0 \%$ in Turkey, $0.50 \%$ in exotic Chickens and $7.50 \%$ Local Chicken. This result shows locally bred chicken is the highest in moisture content compared to $5.00 \%$ in Turkey and $0.50 \%$ in exotic chicken. Moisture in food determines the keeping qualities of food. It also enhance the rate at which absorption takes place within the digestive system and influences the rate at which enzyme activities takes place on the food. The result shows that the local chicken's meat will be easily absorbed by the body, while that of exotic chicken will be least available for absorption in the body.

The percentage of crude protein is $67.59 \%$ in Turkey, $68.95 \%$ in exotic Chicken and $50.95 \%$ local chicken. The $\%$ of protein in locally bred chicken shows that it is a good source of proteins; however, this value is lower than $68.95 \%$ for exotic chicken and $67.59 \%$ obtained for Turkey as shown in table 1. Proteins are powerful compounds that build and repair tissues; it also helps to maintain the body's structure. Protein speeds up chemical reaction in the body, serves as chemical messenger, fight infection and transport oxygen from the lungs to the body tissue. Turkey has recently been shown to fall into a group of high-protein foods (including tuna and egg whites) that can help keep post-meal insulin levels within a desirable range.

The crude fat determined was $18.06 \%$ for Turkey, $3.70 \%$ for exotic chicken and $11.76 \%$ for local chicken. Turkey has the highest crude fat percentage followed by $11.56 \%$ for local chicken and the least value is determined in exotic chicken which is $3.70 \%$. The higher percentage of fat in Turkey and local chicken meat may be responsible for their juiciness and sweet aroma upon cooking. The significant differences in the three results may be due to the facts that exotic chicken feeds mainly on concentrates and are hardly fat-rich, while both Turkey and local Chicken are scavengers who have access to more fat-rich foods than the exotic chicken which are usually kept in cages. The crude fat determined in exotic chicken $3.70 \%$ is close to the crude lipid value $(2.87 \%)$ in a previous report (Nwosu 1980). Fats play an important role in building the membranes that surround our cells in helping blood to clot. Also, presence of fat in the right proportion in the body helps the body to absorb certain vitamins and also to prevent the body from extreme cold and heat.

It has been reported that Chicken meat contains about two to three times as much polyunsaturated fat than most types of red meat when measured as weight percentage.( USDA 1990). Chicken fat is mostly found in the skin. Out of the three meats under consideration Turkey meat has the highest crude fat content this confirms 
a report that fat and protein content of Turkey depend upon the diet that the turkey has been fed. Studies involving the use of linseed oil (flax oil), fish oil, and coconut oil in poultry feed all show a relationship between these fat-based feed components and the composition of the turkey meat." Total fat can be obtained from crude fat by multiplying it with a factor of conversion $(0.8)$ therefore the total fat of turkey is $14.45 \%$, for exotic chicken is $2.96 \%$ and for locally bred chicken the total fat is $9.41 \%$

The percentage of crude fibre is $2.22 \%$ in Turkey and $1.96 \%$ in local chicken. Crude fibre was not detectable (ND) in exotic chicken. This agrees with a previous report [9] where all the meat types analyzed including exotic Chicken had no crude fibre. Dietary fibre helps to reduce serum cholesterol level, risk of coronary heart disease, colon and breast cancer and hypertension. Fibres in food also help in maintaining blood sugar level thus lower the risk of cardio vascular disease.

Out of the three meat samples considered local Chicken has $25.83 \%$ of carbohydrate, this is the highest compared to the ones obtained for Turkey which is $0.63 \%$ and $22.83 \%$ for Exotic chicken. Locally bred chickens feed mainly on carbohydrate rich foods such as maize and guinea corn in their wandering and scavenging, thus a good source of energy and fibre. Carbohydrate content contributes to sweetness, appearance and external characteristics of such foods. No wonder the local chicken has a sweeter taste compared to the exotic chicken.

Table 2: Mineral elements in the three meat samples in $\mathrm{mg} / 100 \mathrm{~g}$ by Atomic absorption Spectrophotometer $\mathrm{ND}=$ not detectable

\begin{tabular}{|c|c|c|c|}
\hline $\begin{array}{l}\text { Mineral } \\
\text { (mg/100g) }\end{array}$ & $\begin{array}{l}\begin{array}{l}\text { Gallus } \\
\text { chicken) }\end{array} \\
\end{array}$ & $\begin{array}{l}\begin{array}{l}\text { Gallus } \\
\text { chicken) }\end{array} \quad \text { gallus(exotic } \\
\end{array}$ & $\begin{array}{l}\text { MeleagrisGallopavo( } \\
\text { Turkey) }\end{array}$ \\
\hline $\mathrm{K}^{+}$ & 704 & 527 & 603 \\
\hline $\mathrm{Na}^{+}$ & 351 & 345 & 370 \\
\hline $\mathrm{Ca}^{2+}$ & 428 & 375 & 575 \\
\hline $\mathrm{Mg}^{2+}$ & 377 & 256 & 370 \\
\hline $\mathrm{P}^{3+}$ & 29.50 & 39 & 29.50 \\
\hline $\mathrm{Fe}^{3+}$ & 465 & 385 & 233 \\
\hline $\mathrm{Mn}^{2+}$ & 245 & 263 & 241 \\
\hline $\mathrm{Cu}^{2+}$ & 26 & 25 & 43 \\
\hline $\mathrm{Pb}^{2+}$ & ND & ND & ND \\
\hline $\mathrm{Zn}^{2+}$ & 594 & 622 & 475 \\
\hline
\end{tabular}

Table 2 above presents the concentration of dietary minerals in the three poultry meats under consideration. The Potassium $\left(\mathrm{K}^{+}\right)$content ranged from $704 \mathrm{mg} / 100 \mathrm{~g}$ in Local chicken to $527 \mathrm{mg} / 100 \mathrm{~g}$ in Exotic chicken. The amount of Sodium $\left(\mathrm{Na}^{+}\right)$ranged from $370 \mathrm{mg} / 100 \mathrm{~g}$ obtained in Turkey to $345 \mathrm{mg} / 100 \mathrm{~g}$ obtained in exotic chicken. Potassium and Sodium work together in muscle contraction nerve transmission. Sodium ions are the main regulators of extra cellular fluid and volume (Whitney and Rofles2002). Recommended daily allowance (RDA) for potassium is $4700 \mathrm{mg}$ that means that $704 \mathrm{mg}$ in Local chicken provides about $14.98 \%$ of the daily recommended value

The concentration of Calcium ranged from $575 \mathrm{mg} / 100 \mathrm{~g}$ in Turkey to $428 \mathrm{mg} / 100 \mathrm{~g}$ in Local Chicken. Locally breed chicken supposed to suffer for calcium and phosphorus because the only source of these two minerals is when it mistakenly picked stone during feeding. Calcium is responsible for strong bones and teeth and accounts for ninety percent of the calcium in the body whereas the other one percent is circulating in the fluids in order to ionize calcium. Calcium metals also help in transmission of nerves impulses, in contractions of muscle, in blood clothing, in activation of enzyme reactions and secretion of hormone. This indicates that local chicken is very rich in calcium and should be consumed by both young and old people. The RDA value for Calcium is $1300 \mathrm{mg}$, Calcium in Turkey can provide about $44.23 \%$ of the daily recommended value.

The Magnesium content $\left(\mathrm{Mg}^{2+}\right)$ ranged from $377 \mathrm{mg} / 100 \mathrm{~g}$ in Local chicken to $256 \mathrm{mg} / 100 \mathrm{~g}$ in exotic chicken as shown in table 2 above. Magnesium helps in supporting the functioning of immune system; assists in preventing dental decay by retaining the calcium in tooth enamel; it has an important role in the synthesis of proteins, fat, nucleic acid, glucose metabolism as well as membrane transport system of cells. The RDA value of magnesium is $420 \mathrm{mg}$; the Magnesium in local chicken can provide $87.76 \%$ of the daily recommended value. The concentration of Phosphorus in both Turkey and Local chickens are the same which is $29.50 \mathrm{mg} / 100 \mathrm{~g}$ but lower than $39.00 \mathrm{mg} / 100 \mathrm{~g}$ in Exotic chicken as shown in table 2.

The content of Iron $\left(\mathrm{Fe}^{2+}\right)$ ranged from $465 \mathrm{mg} / 100 \mathrm{~g}$ in local chicken to $233 \mathrm{mg} / 100 \mathrm{~g}$ in Turkey. Iron is the central metal in the haemoglobin molecule for oxygen transport in the blood and is present in myoglobin located in muscles. Other food materials rich in iron include liver, leaf vegetables, beans, egg etc. Iron is an important mineral that many people don't get enough of. The daily requirement of Iron for adults is $8 \mathrm{mg}$ for 
men and $18 \mathrm{mg}$ for menstruating women to compensate for the losses of iron with the monthly menstrual cycle. The Iron in locally bred chicken has higher value compared to exotic chicken and Turkey.

The Manganese content ranged from $263 \mathrm{mg} / 100 \mathrm{~g}$ in exotic chicken to $241 \mathrm{mg} / 100 \mathrm{~g}$ in Turkey. Exotic chicken has the highest value here, while turkey has the least value. One 3-oz. serving of ground turkey is reported to provide $24 \mathrm{mg}$ of Magnesium. This vital mineral helps the body produce energy from the food we eat, in addition to its role in bone health. (Mensah et al., 2002) The daily requirement for Magnesium for adults over age 30 is $420 \mathrm{mg}$ for men and $320 \mathrm{mg}$ for women. The Copper $\left(\mathrm{Cu}^{2+}\right)$ content of local chicken and exotic chicken are so close in value ,e value was $26 \mathrm{mg} / 100 \mathrm{~g}$ in locally bred chicken and $25 \mathrm{mg} / 100 \mathrm{~g}$ in exotic chicken. Copper in Turkey is $43 \mathrm{mg} / 100 \mathrm{~g}$ which is higher than the other two. Copper assists in the formation of haemoglobin. It also helps to prevent anemia, it is also involved in several enzymatic actions. Manganese is one of the co-factors in a number of enzymes just as molybdenum.

Lead $\left(\mathrm{Pb}^{2+)}\right.$ was not detected in any of the four meat samples, this is much expected since Lead is not a dietary mineral rather it is a toxic metal that is harmful to plant, animals and humans even in low concentrations. Zinc content ranged from $622 \mathrm{mg} / 100 \mathrm{~g}$ in exotic chicken to $457 \mathrm{mg} / 100 \mathrm{~g}$ in Turkey as shown in table 2 above. This important mineral is vital for wound healing and to keep the immune system strong. The daily requirement for zinc for adults is $11 \mathrm{mg}$ for men and $8 \mathrm{mg}$ for women.

\section{Conclusion}

The study of the nutritive value of the sampled meat has shown that turkey meat has the highest crude fat and protein content depending on the type of diet been fed with.Local chicken taste sweeter than exotic chicken,compared to the due to its higher carbohydrate content than exotic chicken.

\section{References}

[1] S. N Ibe. (1998) Improving productive adaptability of the Nigeria local chicken. Proc. of the Silver Anni. Conf. of NSAP held March 1998 at Abeokuta Nig. Pp 404-465.

[2] C.O.N Ikeobi,.M.O. Ozoje, O.A. Adebambo, J.A. Adenowo and O.A. Osinowo, (1996). Genetic differences in the performance of local chicken in South Western Nigeria. Nig. J. Genet., 9: 33-39.

[3] C.C.Nwosu, 1979. Characterization of the local chicken in Nigeria and its potential for egg and meat production. Proceedings of the 1st National Seminar on Poultry Productio, Dec. 11-13, Ahmadu Bello University, Zaria, pp: 187-210.

[4] UF researchers discover earliest use of Mexican turkeys by ancient Maya", at Eurekalert August 8, 2012 (1 n2 )

[5] Cecil Adams."Why can't you buy turkey eggs in stores?".The Straight Dope. Retrieved November 25, 2010.

[6] O.A. Adebambo, 1992. Proposed national animal breeding programmes in Nigeria. Proceedings of the Research Planning workshop, African Animal Genetic Resources, Feb. 19-21, International Livestock Center for Africa, Addisa Ababa, Ethiopia, pp: 137-139.

[7] O.A., Adebambo, 2005. Indigenous poultry breeds genetic improvement for meat and eggs. Proceedings of the 1st International Poultry Summit, Feb. 20-25, Ota, Ogun State, pp: 1-8.

[8] O.R Adeniyi. et al (2011) in their paper titled" Proximate Composition and Economic Values of four Common Sources of Animal Protein in South-Western Nigeria

[9] C.C Nwosu., F.C. Obioha, G. Fred, T. C. Belonwu, G.I. Onuora and S.S.I. Omeje, 1980. A study of the growth pattern of local and exotic chickens. Nig. J. Animal Prod., 7: 38-38.

[10] AOAC (2003). Official Method of Analysis of AOAC International (1 $17^{\text {th }}$ ed) Gaithersburg, MD, USA: Association of Official Analytical Chemist (AOAC) International.

[11] AOAC, 1990. Official Method of Analysis (15th Ed.). Assoc. Offic. Anal. Chem., Washington, DC.

[12] Feinberg School Nutrition Fact Sheet: Lipids Northwestern University. Retrieved on August 24, 2009

[13] USDA Food and Nutrient Database: Ground TurkeyLinus Pauling Institute at Oregon State University: Micronutrient Information Center.S

[14] F.O. Ajayi , 2010. Nigerian Indigenous Chicken: A Valuable Genetic Resource for Meat and Egg Production. Asian Journal of Poultry Science, 4: 164-172.DOI: 10.3923/ajpsaj.2010.164.172.URL: http://scialert.net/abstract/?doi=ajpsaj.2010.164.172 Received: July 23, 2010; Accepted: August 11, 2010; Published: October 08, 2010.

Table 1: Proximate composition of the meats in percentage (\%)

\begin{tabular}{|l|l|l|l|l|l|l|}
\hline Sample & $\begin{array}{l}\text { Moisture } \\
\text { content }\end{array}$ & $\begin{array}{l}\text { Ash } \\
\text { content }\end{array}$ & $\begin{array}{l}\text { Fat } \\
\text { content }\end{array}$ & $\begin{array}{l}\text { Fibre } \\
\text { content }\end{array}$ & $\begin{array}{l}\text { Protein } \\
\text { content }\end{array}$ & $\begin{array}{l}\text { Carbohydrate } \\
\text { content }\end{array}$ \\
\hline $\begin{array}{l}\text { G.gallusdomesticus } \\
\text { (Local chicken) }\end{array}$ & 7.50 & 2.00 & 11.76 & 1.96 & 50.95 & 25.83 \\
\hline $\begin{array}{l}\text { M. } \\
\text { Gallopavo(Turkey) }\end{array}$ & 5.00 & 6.50 & 18.06 & 2.22 & 67.59 & 0.63 \\
\hline $\begin{array}{l}\text { Gallus domesticus } \\
\text { (Exotic Chicken) }\end{array}$ & 0.50 & 4.00 & 3.70 & ND & 68.97 & 22.83 \\
\hline
\end{tabular}

$\mathrm{ND}=$ not detectable at that limit. 
The Nutritive Value Of The Meat Quality Of Locally Breed Chicken, Exotic Chicken And Turkey

Table 2 : Mineral elements in the three meat samples in $\mathrm{mg} / 100 \mathrm{~g}$

\begin{tabular}{|c|c|c|c|}
\hline $\begin{array}{l}\text { Mineral } \\
(\mathrm{mg} / 100 \mathrm{~g})\end{array}$ & $\begin{array}{l}\begin{array}{l}\text { Gallus } \\
\text { chicken) }\end{array} \\
\text { gallus(local }\end{array}$ & $\begin{array}{ll}\begin{array}{l}\text { Gallus } \\
\text { chicken) }\end{array} & \text { gallus(exotic } \\
\end{array}$ & MeleagrisGallopavo(Turkey) \\
\hline $\mathrm{K}^{+}$ & 704 & 527 & 603 \\
\hline $\mathrm{Na}^{+}$ & 351 & 345 & 370 \\
\hline $\mathrm{Ca}^{2+}$ & 428 & 375 & 575 \\
\hline $\mathrm{Mg}^{2+}$ & 377 & 256 & 370 \\
\hline $\mathrm{P}^{3+}$ & 29.50 & 39 & 29.50 \\
\hline $\mathrm{Fe}^{3+}$ & 465 & 385 & 233 \\
\hline $\mathrm{Mn}^{2+}$ & 245 & 263 & 241 \\
\hline $\mathrm{Cu}^{2+}$ & 26 & 25 & 43 \\
\hline $\mathrm{Pb}^{2+}$ & ND & ND & $\mathrm{ND}$ \\
\hline $\mathrm{Zn}^{2+}$ & 594 & 622 & 475 \\
\hline
\end{tabular}

